\title{
Paul Ricoeur on the Recognition of Anxiety: Phenomenological Hermeneutics in Action
}

\author{
K.I. Khan $\bowtie$ \\ RUDN University, \\ Miklukho-Maklaya St., 6, Moscow, 117198, Russian Federation, \\ National Research University "Higher School of Economics", \\ 20, Myasnitskaya St., Moscow, 101000, Russian Federation \\ $\bowtie$ khan-ei@rudn.ru
}

\begin{abstract}
The philosophical concept of anxiety, which is usually associated with Kierkegaard and Heidegger's existential philosophy, seems to be an underestimated notion in Paul Ricoeur's phenomenological hermeneutics, while its role is important - anxiety appears to serve as the grounding for hope in his hermeneutics of self. The article aims to show how the anxiety is explained in Ricoeur's philosophy through attention and recognition, and how the anxiety is reflected in the narrative forms, or descriptions of vivencia. These descriptions may be seen as the verbal explanation of the so-called affective niche or affective scaffolding, which is a form of cultural adaptation, attempting to interpret and comprehend one's state of mind and way of the perception of the world as such in the given moment. The research and further dialogue based on these narrations may become an important source to recover from anxiety disorder, by discovering its existential meaning and, at the same time, accepting personal responsibility for it. Ricoeur's phenomenological hermeneutics made an important theoretical contribution in understanding the essential aspects of anxiety and hope; but it also developed prolific methods of interpretation, that could be practically applied in health care and psychotherapy; these can be shown on the example of the psychotherapeutic method of the usage of so-called 'anxiety protocols', which aim to arrange the hermeneutical co-research to help patient/client to recognize and overcome its anxiety disorders.
\end{abstract}

Keywords: Paul Ricoeur, affective niche, anxiety, attention, phenomenological hermeneutics, psychotherapy, recognition

\section{Article history:}

The article was submitted on 20.02.2021

The article was accepted on 18.08.2021

(C) Khan K.I., 2021

This work is licensed under a Creative Commons Attribution 4.0 International License https://creativecommons.org/licenses/by/4.0/ 
For citation: Khan K.I. Paul Ricoeur on the Recognition of Anxiety: Phenomenological Hermeneutics in Action. RUDN Journal of Philosophy. 2021;25(3):470 - 482. DOI: $10.22363 / 2313-2302-2021-25-3-470-482$

I am, O Anxious One. Don't you hear my voice surging forth with all my earthly feelings?

They yearn so high, that they have sprouted wings and whitely fly in circles round your face.

My soul, dressed in silence, rises up and stands alone before you: can't you see?...

R.M. Rilke

Paul Ricoeur is one of those thinkers who seems to demonstrate high resistance towards classifications, and it's practically impossible to consider him as a representative of one particular philosophical lineage or realm. While nowadays his name is commonly associated with hermeneutics, phenomenology and analytical philosophy, and so many literature was written on his ethics, social and political thought - his theoretical contribution to the understanding the issue of affectivity is still underestimated. Therefore I would like to focus on Ricoeur's notion of anxiety (l'angoisse), interpreted as true or false, and its relation to his hermeneutics of recognition (reconnaissance).

The term of anxiety has become one of the benchmarks in Heidegger's Dasein analytic; it has also been a remarkable concept in Kierkegaard's philosophy, but the historical aspect of anxiety associated with the method of the recognition of the anxiety wasn't that much thematised in terms of practical philosophy before Ricoeur. Moreover, Ricoeur's notion is distinctive due to his phenomenological and hermeneutic approach: we could expect the requirement to be distracted of one's own mood and feelings while trying to understand different prospectives and interpretations - but it is not the case of the Ricoeurienne hermeneutics of the Self. Facing the necessity to choose from equally grounded competing versions or even paradigms of interpretation makes us reflect upon our decision, which are always arbitrary and have the affective ground behind. One's own choice implies one's affection, the attempt to interpret one's own life through this choice, the attention and the interest towards the issue ${ }^{2}$. As long as ut is impossible to grasp the whole hermeneutical project of Ricoeur in the article, I would focus on the analyses of his notions of attention and anxiety in the first section, and the recognition - in the second part, and then turn to the questions of the practical application of Ricouer's phenomenological hermeneutics in psychotherapy.

\footnotetext{
${ }^{1}$ Quotation from R.M. Rilke's poem "The Book of Hours" [1. P. 116]. See original poem in German [Ibid. P. 347].

2 "A purely semantic elucidation remains suspended until one shows that the understanding of multivocal or symbolic expressions is a moment of self-understanding; the semantic approach thus entails a reflective approach. But the subject that interprets himself while interpreting signs is no longer the cogito: rather he is a being who discovers, by the exegesis of his own life, that he is placed in being before he places and possesses himself... Reflection alone, by suppressing itself as reflection, can reach the ontological roots of understanding" [2. P. 11].
} 
Attention in Ricoeur's approach to the understanding tends to play the same role that Stimmung has in Heidegger's fundamental ontology. Unlike Heidegger, Ricoeur tends to speak about the anxiety not only in its existential mode (which may lead to a more profound, authentic and responsible attitude towards life), but he also demonstrates the historical and social dimensions of the anxiety of the present time. Ricoeur pays special attention to the condition of anxiety as a social phenomenon, which is based on overestimated beliefs, the awareness of lack of meaning, the collective state of boredom, and the interconnection of anxiety with the feelings of guilt and hope. The matter of attention and recognition, which lacks the philosophical explanation, stands for the epistemological foundation for the reflection and interpretation of anxiety. And the interpretation of anxiety may lead us to its overcoming. Putting emphasis on symbolic meaning of anxiety, Ricoeur develops Heidegger's recognition of anxious mode of being-in-the-world on the bases of Aristotelian poetics: "[T]here is no self-understanding that is not mediated by signs, symbols, and texts; in the last resort understanding coincides with the interpretation given to these mediating terms... Perception is articulated, desire is articulated... and hermeneutics aims at a re-collection of meaning in its richest, its most elevated, most spiritual diversity" [3. P. 15-17].

In the last section of this paper I would like to develop the idea of recognition of the presence of anxiety in the so-called "affective niche", or affective scaffolding, which is a form of self-styled environment constructed in everyday life by the particular shaping of the affective tonality of our routines (by colors, music, lightning) ${ }^{3}$ [4]. For this reason I would like to briefly consider two cases of implementing the phenomenological hermeneutics as sufficient approach in the research of anxiety protocols (see Simonÿ et al.' research of nursing protocols and interviews on the patients' lived experience, and Alberto de Castro's implementation of hermeneutic technique) [7-10].

\section{Ricoeur's notion of anxiety: the source for recognition of hope}

On March 2, 1939 Paul Ricoeur participated in the conference of Circle Philosophique de l'Oeste in Rennes (France). The text that he sent for publication was far beyond the required length, nevertheless, the manuscript was published in full to express the support for Ricoeur, who volunteered for the front and soon was captured. This early text, which is entitled A Phenomenological Study of Attention and Its Philosophical Connections, is fulfilled with important intuitions that will be crucial for Ricoeur's philosophy. First of all, he describes the way in which the attention is associated with perception as such in its expression of primary temporal relation to the world, things, and oneself. Ricoeur stresses that attention is not focusing on representation.

There are at least two important aspects in the process of attention: a phenomenon of selection ("this object, and not that other one") and a phenomenon

\footnotetext{
${ }^{3}$ Different forms of affective scaffolding as the form of cultural adaptation are also discussed in works of Laland and Colombetti et als. $[5 ; 6]$
} 
of clarity ("I see better"), which is generally summed up in a viewpoint [11. P. 28]. "When I pay attention, my landscape changes aspect, without changing meaning"; but this act itself requires preliminary notice of the perceptibility of the object, which signifies nothing [11. P. 30, 32]. An attentive search can turn out to become either questioning or anticipation. In the case of questioning, the duration of perception is experienced as passive enduring, undergoing, and in the case of anticipation, it is more likely to be perceived as active, dominant; in both cases attention requires some effort. It is important to underline that act of attention (as turning toward to/turning away...) has nothing to do with anticipations such as expecting or looking for - although while we are looking for something there is definitely an act of attention, but these acts should not be mixed up. "The true name for attention is not anticipation but surprise" [11. P. 35-36].

In fact, it is the attention that makes a human being capable of comprehending the truth, and due to the attention, the freedom of will may be observed. The attention always has its limits, that form the unity of an act. This description of attention may be the source for discovering the perspectives for the philosophical search: it appears as questioning (not anticipating), that requires an effort, that is performed through the willingness to search for the truth, and it is shaped as the responsible acting in the world. Unlike act, attention isn't a kind of process that has an end, and unlike cognition, it never results in any idea or certain knowledge; it doesn't form a representation of a thing that has been the object of attention. This notion of attention is crucial for the hermeneutical technique in Ricoeur's thought, which implies understanding as a process, that should be creative, but not productive or representative. The philosophy for him should take the path of recognition (reconnaissance), but not the path of cognition (connaisance) as acquiring specific knowledge.

The notion of anxiety becomes the central topic in one of the essays - Vraie et fausse angoisse (1953), which has been discussed by Ricoeur and Starobinski in Jean Amrouche's programme "Des idées et des hommes" (05.09.1953). That may be important to note, that Ricoeur was quite familiar with psychoanalysis, which was one of the major discourses that he discusses in the "Conflict of interpretations"; therefore, we may assume that the notion of anxiety for him also had the meaning of Freudian Angstneurose ${ }^{4}$. However, the context in which the question of anxiety arises is far from psychology and health science, it rather concerns social issues. Ricoeur attempts to outline a transition from fundamental ontology (he fully accepts Heidegger's claim on the ontological difference) to the interpretation of some particular historical events and texts - or, the possibility of

\footnotetext{
${ }^{4}$ In 1895 Freud introduces the description of Angstneurose in the work "On the grounds for detaching a particular syndrome from neurasthenia under the description 'Anxiety Neurosis"', whereas anxiety stands as the name for umbrella syndrome, including irritability, anxious expectations and worries, that may have a form of exaggerated scrupulousness and pedantry, and somatic ("spasms of the heart", "sweating", etc.) and psychological ("idea of imminent death", "going crazy", etc.) symptoms of anxiety attacks. [12. P. 92-96]
} 
the hermeneutics of the traces of presence. The study of a human being should avoid treating its matter as a subject of research but move towards the reflexive understanding.

In Histoire et vérité Ricoeur introduces the topic of anxiety together with his observations on the civilization of work, where the "self-made man" has become the way, the goal, the object of admiration - and the source of anxiety, while the life seemingly has lost its simplicity [13]. The striving for this simplicity leads Ricoeur towards his ideas of the openness and capacity to act of l'homme capable, with her/his own personal history, who is as personally responsible for her/his own deeds. But this openness often leads into a pitfall of false subjectivity: the human perceives oneself as a combination of identity projects, a set of social roles, duties and statuses of a subject of legal, social and political relations. Ricoeur shows that the origin of this way of subjectivation claims to exhaust the fullness of life without any justification. He writes: "Actually, what my body shows itself to be at first is an openness onto. ... Far from being a closed shell, as Plato put it, or even less an Orphic Tomb, it is openness. And it is this is multiple ways..." [11. P. 306]. This multiplicity (plurivocité) plays pivotal role in both establishing the possibility of freedom - and shows, that the interrelation between me and my symbolic representations of myself in the memories and biographical stories that I tell can be seen as the source for changing and re-thinking. Ricoeur supports the idea of the "talking cure", but not prefers to see it from the perspective of primary fragility and vulnerability - and not necessarily the Oedipus complex. Ricoeur mentions the openness of need which "I" have, belonging to the world, the openness to suffering, that reveals my vulnerability, the openness to participating in a relationship with the Other, the openness of expression, the openness to using and improving my bodily capacities freely. Neither of them should play the major part; the openness can be specified, but the purpose is not in posing the limits of it.

Accordingly, the anxiety arises from the threat of disintegration of Self, of misalignments and mismatches in my life - for instance, due to the frustration caused by constantly making choices from the various desires, goals, projects, aspirations, opportunities and ways. Ricoeur tries to explore not the anxiety as such, but the anxiety of his time by following the maxims: "experience in order to understand", "understand in order to go beyond, or, failing to go beyond, to confront", and, finally follow "the duty to understand our time, if only to speak the language of its anxiety" [13. P. 287-288].

The language of anxiety was associated with the silent speech of Nothingness, the trembling that arises whereas "in anxiety the nothing is encountered at one with beings as a whole... there occurs a shrinking back before" [14. P. 89-90]. The mortality, the finitude of human being reveals the existential aspect of anxiety, its "truth" - but Ricoeur considers this as not sufficient for the explanation, and shows that anxiety is associated with both fear of the unknown and boredom. Production of boredom, which Ricoeur associates with the narrow specialization of labor in industrial societies turned out to be a kind of psychological pain, which causes 
anxiety. Nowadays we could think of the production of anxiety by the raise of selfawareness: the more psychologists and media stress the necessity to take care of yourself, the more responsibility for one's physical and mental health is posed on the rational individual, and the more anxious and neurotized one may become. But the original "guilt" cannot be recognized without the historical and personal context, and it doesn't carry predetermined meaning - so that, for instance, this boredom could be easily replaced by fear and trembling in the face of the harsh living, plague and apocalyptic images in medieval times.

The third aspect of anxiety is a historical one, which deals with political consciousness. The historical anxiety dialectically plays with the ambivalences of expectations and risks: it may interpret the state as both protection and threat, the technical progress as the growth of capacities and as a destructive and dehumanizing power, or consider the atomic weapon as the source of potential conflicts as well as the source of the peace maintenance. Nowadays same logic of ambivalence allows to speak of the same attitude towards AI or the discussions around genetic engineering.

The source of the anxiety, according to Ricoeur, lies in the original guilt: people are responsible for their deeds due to the irreversibility of the events in time. This "natural" aspect of anxiety may be accompanied by metaphysical anxiety, which implies that neither stream of life nor the historical changes have any meaning. This anxiety is rooted in the unpredictability of the future, which is associated with the fear of God's wrath. However, wrath implies hope for mercy. Ricoeur does not want to replace anxiety with blind hope, therefore he refers to Mounier's concept of "tragic optimism" in the face of the ambiguities of history. This "optimism" in his opinion takes its origin from primordial anxiety ${ }^{5}$. The human condition may be seen as the disturbing and anxious mood of the epoch (or even the mood of human existence in the world), which is neither determined by nature nor chosen consciously. But still, a human being can respond personally to this anxious mood by holding awareness of this state of mind, by recognizing its specialty, acknowledging and reflecting it with hope.

Surprisingly, that the hermeneutical approach towards recognition of anxiety is rarely associated with Ricoeur's works. The authors of Le Vocabulaire de Paul

\footnotetext{
5 "Rien n'est plus proche de l'angoisse du non-sens que la timide espérance. Et pourtant cet acte infime opère en silence et tout à la fois se cache et se montre dans sa puissance de récapituler à son tour tous les degrés de l'affirmation originaire. C'est par cette puissance récapitulatrice qu'elle affleure à la réflexion, comme dans un miroir brisé; c'est elle qui anime en sous-main cette reprise d'élan du moi profond fouetté par l'angoisse de culpabilité, et l'optimisme tragique en face de l'ambiguïté de l'histoire et finalement l'énergie psychique elle-même et le simple vouloir-vivre de l'existence quotidienne et mortelle" [Nothing is closer to the anxiety of nonsense than timid hope. And yet this tiny act operates in silence, it hides itself and shows itself at the same time - in its power to recapitulate in turn all the degrees of the original affirmation. It is through this recapitulatory power that it emerges to reflection, as if it was in a broken mirror; it is the reflection which animates this recovery of momentum of the deepest self on the sly, whipped by the anxiety of guilt, and the tragic optimism - in the face of the ambiguity of history, and, finally, the psychic energy itself and the simple willingness-to-live the daily, mortal existence] [15. P. 53].
} 
Ricoeur prefer to speak particularly on the hope (espérance) or the sadness of finitude (tristesse du fini), but not on the issue of anxiety in particular, as it is associated more closely with Heideggerian thought [16]. Rebecca K. Huskey in Paul Ricoeur on hope doesn't even mention anxiety [17]; Kevin J. Vanhoozer prefers to call Ricoeur a "philosopher of hope", mentioning his "conviction of the primordial goodness of things" [18]. Marieke Maes mentions the relation between hope and anxiety, but prefers to speak on the hermeneutics of hope, referring to Kant and Jaspers as well as Christian ethics and influential sources for Ricoeur's thought [19]. Nevertheless, Ricoeur has his explanation of reflection upon anxiety. His goal is not to define the essence of anxiety by applying the method of phenomenological reduction, like Husserl, and not to discover the ontological meaning of anxiety as a phenomenon of a human being as being-present, like Heidegger - his claiming to recognize the anxiety in oneself, and discover the way it reflects and reveals itself in the form of narrative, which is the main "tool" for the hermeneutics of self. Reflection here requires the act of attention towards anxiety - but not remembrance, anticipation, or imagining the state of anxiety; that paying attention does not necessarily mean, that while experiencing anxiety one is incapable of noticing it or describing it. Therefore, reflective recognition moves in the opposite direction with the psychological defense: instead of attempts to get rid of anxiety, it is necessary to reflect upon it in the context of our life as a whole, and this would create a certain distance in the process of reflection with the help of the language as the mediator.

\section{Recognition of vivencia: Ricoeur's narrative approach}

Ricoeur is discovering the interconnection between the philosophy and life experience as vivencia. In his posthumously published notes he stated: "What the horror lays bare is the experience that life has of itself and that the Spanish vivencia conveys better than does the French vécu and even perhaps the German Erlebnis. The make-believe of Death whose meaning I'm trying to exegete starting from extermination up to the massa perdita is so anchored in the vivencia that it becomes indiscernible from the 'bare anxiety of living' in its aspect of 'chance"' [20. P. 32 - 33]. This experience of vivencia becomes a source for the interpretative technique, that uses the phenomenological approach to improve the mutual understanding of "nurse/therapist — patient/client", switching their positions to "researcher/co-researcher", or even "philosopher, which initiates the maieutic of anxiety - the anxious person, which practices self-recognition to find the source for hope". This self-recognition requires the help of the other, as long as anxiety is rooted in our being with the others, and recognition implies mutuality — which, nevertheless, doesn't mean symmetry and is not confused by dissymmetry, as this relationship "I - the Other" is always dissymmetrical, but still reciprocal ${ }^{6}$.

The same logic should be applied for social and political domains - as far as people are concerned about the acceptance of contingency of historical events and

\footnotetext{
${ }^{6}$ See the paragraph "From Dissymmetry to Reciprocity" in: [21. P. 153-161].
} 
the limited capacity to predict them, the anxiety of present time is overcome with the philosophical reflection upon the anxiety and freedom of acceptance and forgiveness.

In his late book The Course of Recognition Ricoeur revises again Rilke's descriptions of anxiety ${ }^{7}$ in his inquiry on recognition as a movement towards change, which may be barely presented as following: from suffering - to the recognition of suffering - to the recognition of responsibility and taking decision for acting - to recognizing the reflexive value in the discovered ability to intervene the world. The concept of recognition (réconnaissance) has its historical roots in Kant's "recognitio", Hegel's "Anerkennung" and Bergsonian "réconnaissance (dans la mémoire)" [21. P. 17-18, 21, 110, 123]. Ricoeur's contribution to this concept may be briefly described as the shift towards overcoming the chance of misrecognition by both accepting it, integrating dissymmetry as beneficial, and impose the anticipation of mutuality of non-identical relation of 'allelon' (one another, each other). The way it can be achieved efficiently is a narration (which tends to become a source for a dialogue, which implies the chance of misunderstanding and the multiple interpretations possible) $)^{8}$.

While vivencia may be presented in the form of a narrative, that has an open ending, according to Ricoeur, the narrative identity which arises from it appears to be the only way to hold to the aim of a "good life" [21. P. 103]. The motive of this narrative interlinks the accomplishing deeds and the recognition of them as valuable; this value can be provided by the force of authority, but Ricoeur introduces a hypothesis that this recognition transforms its communicative form from the struggle for recognition - to the experience of recognition as gratitude in the peaceful state. The struggle for recognition implies power discourse and the Hegelian "unhappy consciousness" that arises from the dialectic of such recognition, as long as the one who recognizes is never equal to the one who wants recognition. This recognition remains non-satisfying whether it is performed by oneself or by another person; the exchange is never fully equal, as no one exchanges the same for the same due to its meaninglessness. The gratitude appears in the case of gift, where the affective intention of giving is interpreted by Ricoeur as the example of generous agape; first of all, it requires good intention towards the future and towards the Other, that can be comprehended in the willingness to give promise and act accordingly.

The practical consequences definition of recognition can seem paradoxical: how the gratuitousness or altruism may be maintained if there is always a chance for misunderstanding? The case is that there is no definite guarantee, only the

\footnotetext{
${ }^{7}$ It is worth noting that Ricoeur often refers to R.M. Rilke while speaking on the issue of anxiety: he mentions Rilke in "Vraie et fausse angoisse", in the discussion on l'angoisse with Starobinsky and Amrouche, speaking about the anxiety of nonreturn in the essay "Recognition as Identification", etc.

${ }^{8}$ This thesis can be explained by following Ricoeur's commentary: "There is no narrative that does not mix together different life stories, as is well documented by literature dealing with selfawareness. The plot is the configuration that weaves together events and characters. Finally, narrating, like saying, calls for an ear, a power to hear, a reception (which stems, moreover, from an aesthetic of reception that is not at issue here)" [21. P. 253].
} 
chance. And this should be kept in mind when proceeding to the practical implementation of this recognition in the case of anxiety. In any case, the capacity to have a peaceful and safe feeling or state needs some experience of a secure life, so that we could recognize this condition and seek for its maintenance. The anxiety as a term is derived from ancient Greek $\ddot{\alpha} \gamma \chi \omega$ - 'chocking, compressing throat', which signifies not only fear and constriction, but also the destiny, or the sense of life [22]. The simple example is breathing: we are usually unaware of this natural process, but as soon as one may experience any difficulty in breathing or lack of oxygen, the need for the air arises as crucial; the responsible and reflective person would take care about the air circulation in any room he would have to stay, especially for a long time. It is possible to imagine that one may prefer to live the life of a constant "diver", preferring the cycles of repetitive exhaustion - such as living in the unconscious disquietude; but at least this person should accept it as her/his own choice, considering the possibility of other options.

\section{Phenomenological-hermeneutical method of anxiety recognition: anxiety protocols and health care as the care for present and future}

Now I am going to switch the perspective from the theoretical framework of anxiety recognition to the study of several cases, that show how Ricoeur's ideas may be efficient and applicable - even though his remarks on "the anxiety of the present time", associated with the political and economical realm of the midtwentieth century, are no longer valid. Ricoeur's hermeneutics became quite an influential approach among several specialists involved in the research of medical rehabilitation, nursing, and psychotherapy; it has a potential to serve as the tool for both discovering the affective niche as the important part of the conditions for rehabilitation or anxiety recovery, and the improving of these conditions.

The group of researchers, including Simonÿ C., Specht K., Andersen I.C., Johansen K.K., Nielsen C., Agerskov H., Bodtger U., Birkelund R. (et al.) adopted a so-called "Ricoeur-inspired qualitative approach" to interpret patients' experience of vivencia; they were inspired by the Danish nursing researcher Birthe D. Pedersen, who in the 1990s took the first steps toward developing a method of interpretation of nurses' experience inspired by Ricoeur's philosophy. Another example of more or less the same technique used is described by Alberto de Castro (although the latter does not refer not to Ricoeur directly, but puts more emphasis on Giorgi's transcendental phenomenological approach, enriched by the ideas of other phenomenologists).

In all the cases mentioned above the "Ricoeur-inspired" approach may be described as following: the textual data is provided from the protocols, which are taken as interviews, together with interviewer's observations, field notes, and own reflections. The collected material "includes not only the patients' verbal expressions but also observations of the context that they are part of with bodily expressions and interactions" [7].

These texts are overviewed for the first time in the form of naïve reading of everything. Then some parts of interviews and notes are supposed to be analyzed 
structurally, forming a protocol (identifying patterns and themes, level of significance and interconnected understanding); the major part of the work deals with the critical discussion (in de Castro's case it was important that both interviewer and the respondent participated in it). De Castro noted, that he "tries to comprehend co-researcher as being anxious-in-the-world and to understand the whole meaning of her experience" [23. P. 147]; the term "co-researcher", introduced by him, appears to be very precise and relevant in that case, as we claim to practice the hermeneutics of self in order to recognize Other's story of her/his vivencia. The interview consists of open questions that are mostly stressing the aspect of personal meaning, in the form of "please describe your experience of...". Mostly the respondents have started with their impressions and the perception of the affective cliché; it turned out that some of them became aware of getting into trouble of anxiety and cardiac problems due to the ignorance of the affective niche they were living in. Basically, the small changes in the everyday habits turned out to be the things that one is capable of changing. Realizing that such actions are relatively easy to perform as they depend entirely on the individual, she or he may see this responsibility not as a burden, but as a task - and thus take the first step towards overcoming anxiety.

What seems to be extremely important from these interviews, is that the reflections upon the rehabilitation process revealed the raise of existential anxiety, as well as the raise of willingness to care about the meaningful life and personal well-being:

"The most novel finding was that the patients were not only supported to cope with the medical situation and follow recommendations of lifestyle but also to find new values in their lives by focusing on their own needs and sense of well-being. The present findings illuminate how the patients received care that addressed their personal needs in ways that enhanced their ability to make decisions in their lives. Moreover, the patients developed a responsibility for their remaining span of time to be both healthier and more worthwhile with respect to their personal well-being" [24].

"When the co-researcher feels that she has not been able to preserve or affirm her concrete meaning, develop her specific projects, and reach her particular goals, the experience of being anxious is not a constructive experience, but a very painful experience. According to what I have seen here, it seems that every goal, intention, and value is affectively placed in a general project of life, and when she feels that she cannot affirm, reach or preserve those goals, intentions or values, she feels that it is her whole project and meaning as a human being that is threatened, and not only a particular and isolated goal, intention or value... she is able to understand that the experience of being anxious is very related to the way she develops and/or affirms her goals, intentions, and projects in life" [23. P. 156-158].

From these two quotations it follows that the anxious experience truly revealed the potential to be the grounding for the positive intentions towards the future. The raise of hope nevertheless required some recognition of the state of anxiety from the other person, to whom the one experiencing anxiety is open (and had the trust 
to share this experience). The narration in the form of anxiety protocols itself already makes the huge part, initiating the personal reflection towards one's sense of existence in the world, namely, finding oneself as l'homme capable.

It seems that rethinking of the anxious experience, following Ricoeur's notions, may be developed in several directions. First of all, person is capable of analyzing the traces of its own self-explanations and manage to discuss, whether the anxious state was induced by personal situation or social/historical/political circumstances. Moreover, it can be seen how the structure of the desired narration affects selfperception and the emotional dynamics. We start any story about our lived experience from the beginning, then we put some intrigue, see what is going on, discover the culmination moments and somehow come to the end. To recognize yourselve in a story means to be capable of making a step outside of it, for a while becoming the narrator, though still being a main character; the Other helps to discuss the variety of interpretations that may be hidden in such story. Sometimes we tend to see ourselves as being in the state of constant struggling efforts, while the hubris of character serves as the dramatic fuel for the inspiring storytelling but does one's life project needs to be tragically heroic, to be seen in brilliant highlights and deep shadows? The symbolical structures of anxiety-protocols may reveal the intentional focuses of our self-cognition - and the recognition of the meaning is required to become responsible for what one can be responsible for and not responsible for those things, which are independent from one's personal willing and acting.

That is astonishing to find that the philosophical turn to the issues of affectivity may have its impact not only as a theoretical contemplation, but as a life-giving source. It might be fair to say, that due to his phenomenological attention to the anxiety, language, self and the other, attention and recognition Paul Ricoeur should be honourably called the philosopher of hope - the hope, which arises from attentive recognition of anxiety and finding a remedy in responsibility for yourself and other people.

\section{References}

[1] Rilke RM. I am, O Anxious One. Don't you hear my voice... (from the Book of Hours, 1905). In The Selected Poetry of Rainer Maria Rilke. Mitchell S, editor, translator. New York: Random House; 1982.

[2] Ricoeur P. The Conflict of Interpretations: Essays in Hermeneutics. Evanston, IL: Northwestern University Press; 1974.

[3] Ricoeur P. On Interpretation. In From Text to Action. Essays in Hermeneutics II. Evanston, IL: Northwestern University Press; 1991.

[4] Krueger J, Osler L. Engineering Affect: Emotion Regulation, the Internet, and the Techno-Social Niche. Philosophical topics. Fall 2019;47(2):205-231. doi: 10.5840/philtopics201947223.

[5] Laland KN, Odling-Smee J, Feldman MW. Niche Construction, Biological Evolution, and Cultural Change. Behavioral and Brain Sciences. 2000;23(1):131-146. doi: 10.1017/S0140525X00002417

[6] Colombetti G, Krueger J. Scaffoldings of the Affective Mind. Philosophical Psychology. 2015;28(8):1—20. doi: http://dx.doi.org/10.1080/09515089.2014.976334 
[7] Simonÿ Ch, Specht K, Andersen ICh, Johansen KK, Nielsen Ch, \& Agerskov H. A Ricoeur-inspired approach to interpret participant observations and interviews. Global Qualitative Nursing Research. 2018. 5: 233339361880739. [Published online: 30.10.2018]. doi: 10.1177/2333393618807395.

[8] Simonÿ Ch, Andersen ICh, Bodtger U \& Birkelund R. Breathing through a troubled life a phenomenological-hermeneutic study of chronic obstructive pulmonary disease patients' lived experiences during the course of pulmonary rehabilitation. International Journal of Qualitative Studies on Health and Well-being. 2019;14(1). [Published online: 21.08.2019]. doi: 10.1080/17482631.2019.1647401.

[9] Singsuriya P. Nursing researchers' modifications of Ricoeur's hermeneutic phenomenology. Nursing Inquiry. 2015;22:348 - 358. doi: 10.1111/nin.12098.

[10] DeCastro A. Proceso experiencial en psicoterapia existencial. In Gomez Salas R, editor. Relación psicoterapéutica. Enfoque fenomenológico-existencial. Lima, Peru: Fondo Editorial de la UIGV; 2013. P. 33-58

[11] Ricoeur P. Philosophical anthropology. Cambridge; Malden: Polity Press; 2016.

[12] Freud S. On the grounds for detaching a particular syndrome from neurasthenia under the description 'Anxiety Neurosis' (J. Strachey, Trans.). In Strachey J, editor. Early psychoanalytic publications. Vol. 3. P. 87-139. London: The Hogath Press; (1953) 1975.

[13] Ricoeur P. History and Truth. Evanston, IL: Northwestern University Press; 1965.

[14] Heidegger M. What Is Metaphysics? In Pathmarks. [McNeill W, editor; Krell DF, translator]. Cambridge University Press; 1998.

[15] Ricoeur P. Vraie et fausse angoisse. (Conférence du 3 septembre). L'angoisse du temps présent et les devoirs de l'esprit. Textes des conférences et des entretiens organisés par les Rencontres Internationales de Genève. Neuchâtel, Les Éditions de la Baconnière; 1953.

[16] Abel O, Porée J. Le Vocabulaire de Paul Ricoeur. Paris : Ellipses Édition Marketing S.A.; 2007.

[17] Huskey R. Paul Ricoeur on hope: expecting the good. Phenomenology and literature, vol. 6. New York: Peter Lang Publishing Inc.; 2009.

[18] Vanhoozer KJ. The Joy of Yes: Ricoeur: Philosopher of Hope. The Christian Century. August 23, 2005. URL: https://www.christiancentury.org/article/2005-08/joy-yes.

[19] Maes M. Hope, hermeneutics and eschatology. Based on the philosophy of Paul Ricour. [Conference paper]. Conference: Ecumenical Reception and Critique of TwentiethCentury Orthodox Theology in Exile and Diaspora. Prague; 2015.

[20] Ricoeur P. Living up to Death. Translated by D. Pellauer. The University of Chicago Press; 2009.

[21] Ricoeur P. The Course of Recognition. [D. Pellauer, translator]. Cambridge, Massachusetts: Harvard University Press; 2005.

[22] López-Ibor JJ, López-Ibor MI. Anxiety and logos: toward a linguistic analysis of the origins of human thinking. Journal of Affective Disorders. 2009;120(1-3):1-11. doi: 10.1016/j.jad.2009.02.026.

[23] De Castro A. Hermeneutical understanding of an experience of being anxious. Qualitative Research in Psychology. 2005;2(2):141-167. doi: 10.1191/1478088705qp034oa.

[24] Simonÿ Ch, Dreyer P, Pedersen BD, Birkelund R. Empowered to gain a new foothold in life-A study of the meaning of participating in cardiac rehabilitation to patients afflicted by a minor heart attack. International Journal of Qualitative Studies on Health and Well-being. 2015;10 (1):28717. doi: 10.3402/qhw.v10.28717.

\section{About the author:}

Khan Kate Innokentievna - assistant lecturer, RUDN University, Chair of Ontology and Epistemology; PhD student, National Research University "Higher School of Economics", School of Philosophy and Cultural Studies, Faculty of Humanities; Moscow, Russia (e-mail: katerina.inno@gmail.com). 


\title{
Поль Рикёр о признании тревоги: феноменологическая герменевтика в действии
}

\author{
Е.И. Хан $\$ \\ Российский университет дружбы народов, \\ Российская Федерачия, 117198, Москва, ул. Миклухо-Маклая, 6, \\ Национальный исследовательский университет «Высшая школа экономики», \\ Российская Федерачия, 101000, Москва, ул. Мясниикая, 20 \\ $\bowtie$ khan-ei@rudn.ru
}

\begin{abstract}
Аннотация. Роль философского понятия тревоги, обычно ассоциируемого с экзистенциальной философией Кьеркегора или Хайдеггера, также играет весьма важную роль в феноменологической герменевтике Поля Рикёра, которая остается недооцененной несмотря на то, что тревога выступает в качестве основания надежды в рамках герменевтики себя. Данная статья демонстрирует, каким образом через «внимание» и «признание» в философии Рикёра понимается тревога, и каким образом она находит свое выражение в повествовательных формах, или в описании vivencia (живого опыта). Подобного рода дескрипции могут пониматься как словесное отражение т.н. «аффективного поля», или «аффективных лесов», которые выступают как способ культурной адаптации, попытка истолковать и понять свое состояние сознания и способ мировосприятия в указанный момент. Исследование подобных повествований, а также последующая беседа на их основе, могут стать важным источником исцеления от тревожных расстройств благодаря открытию экзистенциального смысла тревоги, а также в ходе принятия за нее личной ответственности. Феноменологическая герменевтика Рикёра вносит ценный теоретический вклад в понимание сущностных аспектов тревоги и надежды и, вместе с тем, предлагает продуктивные методы интерпретации, которые могут быть применены в медицинской и психотерапевтической практике. Предлагается анализ конкретных примеров использования в психотерапии т.н. «протоколов тревоги», представляющих собой попытку организовать совместное герменевтическое исследование, в рамках которого пациент/клиент признает и преодолевает свое тревожное расстройство.
\end{abstract}

Ключевые слова: Поль Рикёр, аффективное поле, тревога, внимание, феноменологическая герменевтика, психотерапия, признание

\section{История статьи:}

Статья поступила 20.02.2021

Статья принята к публикации 18.08.2021

Для цитирования: Khan K.I. Paul Ricoeur on the Recognition of Anxiety: Phenomenological Hermeneutics in Action // Вестник Российского университета дружбы народов. Серия: Философия. 2021. Т. 25. № 3. С. 470 - 482. DOI: 10.22363/2313-2302-2021-25-3-470-482

\section{Сведения об авторе:}

Хан Екатерина Иннокентьевна - ассистент кафедры онтологии и теории познания, Российский университет дружбы народов; аспирант Школы философии и культурологии факультета гуманитарных наук, Научно-исследовательский университет «Высшая школа экономики», Москва, Россия (е-mail: katerina.inno@gmail.com). 